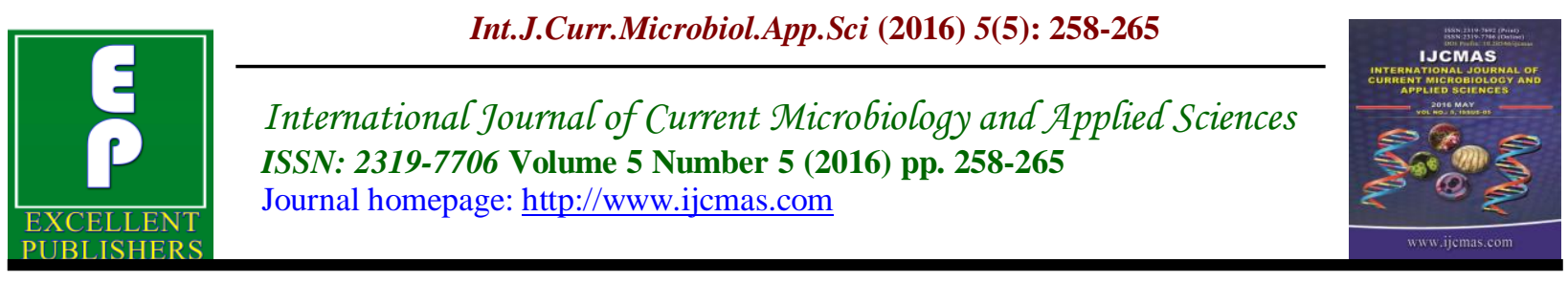

Original Research Article

http://dx.doi.org/10.20546/ijcmas.2016.505.028

\title{
Biodegradation of Deltamethrin by using Indigenous Bacteria Isolated from Contaminated Soil
}

\author{
A.S. Pawar ${ }^{1 *}$, G.V. Mali ${ }^{1}$ and H.V. Deshmukh ${ }^{2}$ \\ ${ }^{1}$ Bharati Vidyapeeth's, M. B. S. K. Kanya Mahavidyalaya, Kadegaon, Dist. Sangli (MS), India \\ ${ }^{2}$ Rayat Institute of Research and Development, Satara (MS), India \\ *Corresponding author
}

\begin{tabular}{|c|c|}
\hline & A B S T R A C T \\
\hline Keywords & \multirow{4}{*}{$\begin{array}{l}\text { Deltamethrin [(S)- } \alpha \text {-cyano-( } 3 \text {-phenoxyphenyl) methyl3-(2,2-dichlorovinyl)- } \\
2,2 \text { dimethylcyclopropane carboxylate] is one of the most frequently and } \\
\text { widely used pyrethroids against a broad spectrum of insect pests of } \\
\text { economically important crops. It is also used for the control of household } \\
\text { insect pests such as mosquitoes, cockroaches, flies, termites, and fleas. It is } \\
\text { widely used in agriculture because of its persistence, residual activity and } \\
\text { low toxicity to mammals. This pesticide is neurotoxic, carcinogenic and its } \\
\text { long exposure produces long term diseases. Present work was aimed with } \\
\text { the biodegradation of deltamethrin insecticide by using indigenous bacteria } \\
\text { isolated from contaminated soil. It describes the biodegradation of } \\
\text { deltamethrin by bacterial isolate IK2a which degrades deltamethrin into non } \\
\text { toxic metabolites like benzene dicarboxylic acid, benzene and propane. It } \\
\text { was confirmed by FTIR and GCMS analysis. }\end{array}$} \\
\hline $\begin{array}{l}\text { Biodegradation, } \\
\text { Pesticide, } \\
\text { Deltamethrin, } \\
\text { neurotoxic, } \\
\text { carcinogenic } \\
\text { FTIR, } \\
\text { GCMS. }\end{array}$ & \\
\hline Article Info & \\
\hline $\begin{array}{l}\text { Accepted: } \\
\text { 15 April } 2016 \\
\text { Available Online: } \\
10 \text { May } 2016\end{array}$ & \\
\hline
\end{tabular}

\section{Introduction}

The pyrethroid pesticides are extensively used in agriculture, animal health, home, and garden pest control since their discovery and commercial development (Elliott 1995). These synthetic pyrethroids are derived from the naturally occurring pyrethrins from chrysanthum flower (Laffin et al., 2010). The basic characteristic structure of these pesticides as an acid joined to an alcohol by an ester bond. They have potent neurotoxic activity against insects and low toxic for mammals. Therefore, they are replacement for more toxic or recalcitrant organochlorines or organophosphates (Katsuda 1999). In recent year pyrethroid pesticide account for $25 \%$ of the global insecticide market (Zhang et al., 2010).

Deltamethrin [(S)- $\alpha$-cyano-(3-phenoxyphenyl) methyl3-(2,2-dichlorovinyl) -2,2 dimethylcyclopropane carboxylate] is one of the most frequently and widely used pyrethroids against a broad spectrum of insect pests of economically important crops. It is also used for the control of household insect pests such as mosquitoes, 
cockroaches, flies, termites, and fleas. Deltamethrin is having strong adsorption ability on particles and therefore, it is immobile in the environment. It is soluble in water and it has very low rate of application. However, if it is applied it is still dangerous to the ecosystem (Bhanu et al., 2011). Deltamethrin is widely used in agriculture because of its persistence, residual activity and low toxicity to mammals (Lawskowski, 2002).

Many studies have shown that pyrethroids may have cumulative toxicity (Liu et al., 2010), reproductive toxicity (Perry et al., 2007; Abdallah et al., 2009), neurotoxicity (Shafer et al., 2005; Wolansky and Harrill 2008), and endocrine disruption effects on non-target creatures (Zhao et al., 2008; McKinlay et al., 2008). Long term exposure to these kinds of pesticides may lead to some chronic diseases (Wang et al., 2009b; Aksakal et al., 2010). Some of them are considered as a possible human carcinogen (Shukla et al., 2002; Zhang et al., 2010). However, out of total pesticide applied to agricultural field, $0.1 \%$ reaches the target pest and remaining affects the environment ( Ardley., 1999).

All these factors together make pyrethroids potentially harmful to human health and ecosystem. Therefore, it is necessary to develop remediation strategies to degrade and eliminate pyrethroid residues from the environment. The present work was aimed with the degradation of deltamethrin insecticide by using indigenous bacteria isolated from contaminated soil.

\section{Materials and Methods}

\section{Pesticides}

Deltamethrin with trade name Decis (Bayer Crop Science Ltd.) was collected from local market of Sangli. Its chemical composition was Deltamethrin $11.00 \%$ w/w.

\section{Soil Enrichment Technique for Isolation of Deltamethrin Degrading Bacteria}

Soil samples collected from the top $0-15 \mathrm{~cm}$ of field plots were air dried to $20 \%(\mathrm{w} / \mathrm{w})$ moisture content (Dubey and Fulekar, 2011). 50 grams of each sample was placed in six glass plates and covered to maintain moisture conditions. The samples were then treated with aqueous solution of Deltamethrin to get final concentration of $100 \mathrm{ppm}$ and incubated at room temperature for two weeks by mixing gently. The moisture content was maintained using distilled water. The insecticide treatment was repeated three times at every two week of time interval.

\section{Screening and Selection of Deltamethrin Degrading Microorganisms}

The soil samples (5 to $10 \mathrm{gm}$ ) were inoculated in mineral salt medium supplemented with deltamenthrin in 10ppm concentration for the enrichment of pesticide degrading bacteria. It was kept on rotary shaker operating at $250 \mathrm{rpm}$ for seven days at room temperature (ranged from 25 $28^{\circ} \mathrm{C}$ ). A loop full of enriched culture from the flasks was streaked on minimal agar plates supplemented with varying concentrations of deltamethrin (up to 100 ppm) and incubated at $37^{\circ} \mathrm{C}$ for $24-48 \mathrm{hr}$. Individual colonies were subcultured on minimal agar plates containing same concentration of deltamethrin until pure culture was isolated. The isolates showing the highest degree of tolerance were maintained on agar slant at $4^{\circ} \mathrm{C}$ and sub cultured after every three months.

\section{Medium for Biodegradation}

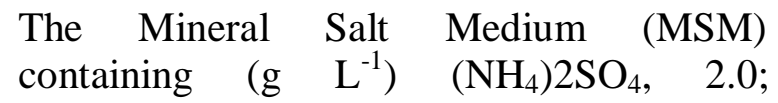


$\mathrm{MgSO}_{4} .7 \mathrm{H}_{2} \mathrm{O}, \quad 0.2 ; \quad \mathrm{CaCl}_{2} \cdot \mathrm{H}_{2} \mathrm{O}, \quad 0.01$; $\mathrm{FeSO}_{4} .7 \mathrm{H}_{2} \mathrm{O}, 0.001 ; \mathrm{Na}_{2} \mathrm{HPO}_{4} .12 \mathrm{H}_{2} \mathrm{O}, 1.5$; $\mathrm{KH}_{2} \mathrm{PO}_{4}, 1.5, \mathrm{pH} 7.2$ and supplemented with $10 \mathrm{ppm}$ of deltamethrin as a sole source of carbon and nitrogen was used to study the degradation.

\section{Biodegradation of Deltamethrin}

The isolate was inoculated in an Erlenmeyer flasks containing mineral salt medium of above composition and the flask was incubated at an ambient temperature of $30^{\circ} \mathrm{C}$ at shaking (150 rpm in an orbital shaker) conditions for 8 days. The degradation of deltamethrin was determined after every two days by measuring decrease in $\lambda$ max of the compound at $271 \mathrm{~nm}$. For this, the samples were collected after every two days of incubation and centrifuged at $10000 \mathrm{rpm}$ for 12 minutes in cooling centrifuge adjusted to $4^{0} \mathrm{C}$. The supernatant was taken, filtered through $0.2 \mu \mathrm{m}$ membrane filter and then the filtrate was scanned in the UV- Vis Spectrophotometer (Cyberlab UV 100). The band width was set to $1 \mathrm{~nm}$ during scanning program. Control flask containing synthetic medium but without inoculum was run parallel along with the test flask. The degradation activity was expressed as percent degradation which was calculated by using formula (Rokade and Mali, 2013),

Percent degradation $=\mathrm{Ab}-\mathrm{Aa} / \mathrm{Ab} \mathrm{X} 100$,

Where,

$\mathrm{Ab}$ is absorbance of compound at $271 \mathrm{~nm}$ before degradation and

Aa is absorbance at same wavelength after degradation.

\section{Extraction of Metabolites}

\section{FTIR Analysis}

The biodegradation was also confirmed by
Fourier Transform Infrared Spectrometer (Perkin Elmer Spectrum 65) analysis (Parte et al., 2013). For this, after 8 days of incubation, the culture broth was centrifuged at $6000 \mathrm{rpm}$ for $10 \mathrm{~min}$. and supernatant was separated. Equal volume of ethyl acetate was added to this supernatant and the organic phase containing extracted metabolites was collected. The extract was dried over anhydrous $\mathrm{Na}_{2} \mathrm{SO}_{4}$ and evaporated to dryness in a rotary vacuum flash evaporator. It was then mixed with spectroscopically pure $\mathrm{KBr}$ in the ratio of 5:95 and pressed to obtain IR transparent pellet. The pellet was placed in sample holder and the analysis was carried out in the mid IR region of $500-3500 \mathrm{~cm}^{-1}$ with 16 scan speed.

\section{GCMS Analysis}

For this, the dried metabolites obtained were dissolved in HPLC grade methanol and filtered through $0.2 \mu \mathrm{m}$ membrane filters. The filtrate was then analysed by Gas chromatography (Helwett Packard 984BMS) engine with a Resteck column (0.25 $\mathrm{mm} \times 30 \mathrm{~mm}$; XTI-5) attached to mass spectrometry. The temperature programming mode was adjusted and samples were injected in split less mode. During analysis the initial temperature of column was maintained at $80^{\circ} \mathrm{C}$ for 2 minutes, increasing rate was by $10^{\circ} \mathrm{C}$ and the final temperature was $290^{\circ} \mathrm{C}$ holding for 5 minutes. Helium was used as carrier gas. The compounds were identified on the basis of mass spectra and were compared using National Institute of Standards and Technology (NIST) library.

\section{Statistical Analysis}

All the experiments were carried out in triplicate. Analysis of the variants was carried out on all data at $\mathrm{P}<0.05$ using Graph Pad software. (Graph Pad Instat 
version 3.00, Graph Pad software, San Diego, CA, USA).

\section{Results and Discussion}

\section{Screening of Deltamethrin Degrading Bacteria}

Deltamethrin was used as a sole carbon source in mineral salt medium for the isolation of pyrethroid degrading strains by enrichment technique. In the isolation procedure, 03 strains were able to grow well on MSM agar plates containing $10 \mathrm{ppm}$ of bifenthrin. Pesticide tolerance abilities of these stains were checked by providing higher concentration of pesticide respectively $20 \mathrm{ppm}, 40 \mathrm{ppm}, 60$ ppm, 80 ppm, and $100 \mathrm{ppm}$ concentration and the highest concentration tolerating bacteria was selected and coded as IK2a. This isolate was used for further degradation study.

\section{UV-Vis Analysis of Deltamethrin}

$\mathrm{UV}-\mathrm{V}$ is spectral analysis of cell free broth at 200 to $400 \mathrm{~nm}$ wavelength was carried out to confirm the degradation of deltamethrin. Fig.1 shows the change in the absorbance spectra of deltamethrin before and after degradation by isolate IK2a. Degradation of deltamethrin was found to be $84.15 \%$. At every 2,4,6 and 8 days of incubation there percentage degradation was calculated, it was found to be increasing with decrease in concentration of cypermethrin in (Table 1).

\section{FTIR Analysis}

The difference in FTIR spectrum of Deltamethrin (Fig.2A) and metabolites obtained after its degradation (Fig.2B) confirms biodegradation.

As shown in control peak of deltamethrin in fig. 2A. and degradation peak of deltamethrin in fig. 2B. , =C-H stretching is observed at bond length of 3143.40 to $3097.12 \mathrm{~cm}^{-1} 1$ while $\mathrm{C}-\mathrm{H}$ bond stretching at 3008.41 to $2996.84 \mathrm{~cm}^{-1}$. The peak of $\mathrm{C} \equiv \mathrm{N}$ at $2360.44 \mathrm{~cm}^{-1}$ found to disappears which indicates complete breakdown of Nitrile group. C-O bond stretch was observed from 1068.37 to $1022.09 \mathrm{~cm}^{-1}$ and $\mathrm{C}-\mathrm{Br}$ stretch was observed from 659.54 to $632.54 \mathrm{~cm}^{-1}$. The metabolites formed after degradation of Deltamethrin were further identified by means of GCMS analysis.

\section{Proposed Degradation Pathway}

GCMS anlysis of Deltamethrin shows retention time 19.308 minutes. The result obtained were matched with NIST library database where it is showes retention time of Deltamethrin. The result obtained were matched with respect to mass/charge ratio $\mathrm{v} / \mathrm{s}$ relative intensity. The result obtained from GCMS analysis clearly showes the formation of benzene dicarboxylic acid, benzene and propane from Deltamethrin degradation by isolate IK2a (Fig 3).

Table.1 Percentage Degradation of Cypermethrin after 2,4,6 and 8 Days of Incubation with isolate IK2a

\begin{tabular}{|c|c|c|c|c|c|}
\hline & $\begin{array}{c}\text { Before } \\
\text { incubation }\end{array}$ & $\begin{array}{c}\text { After 2 days of } \\
\text { incubation }\end{array}$ & $\begin{array}{c}\text { After 4 days of } \\
\text { incubation }\end{array}$ & $\begin{array}{c}\text { After 6 days of } \\
\text { incubation }\end{array}$ & $\begin{array}{c}\text { After 8 days of } \\
\text { incubation }\end{array}$ \\
\hline $\begin{array}{c}\text { Wavelength } \\
\text { maxima }\end{array}$ & 271 & 271 & 271 & 271 & 271 \\
\hline $\begin{array}{c}\text { Percentage } \\
\text { degradation }\end{array}$ & $0 \%$ & $15.36 \pm 0.0023 \%$ & $39.42 \pm 0.0023 \%$ & $64.05 \pm 0.0023 \%$ & $84.15 \pm 0.0023 \%$ \\
\hline
\end{tabular}

Values are mean of \pm SEM of three experiments 
Fig.1 UV-Vis Spectra of Deltamethrin Degraded Metabolites after 8 Days Incubation

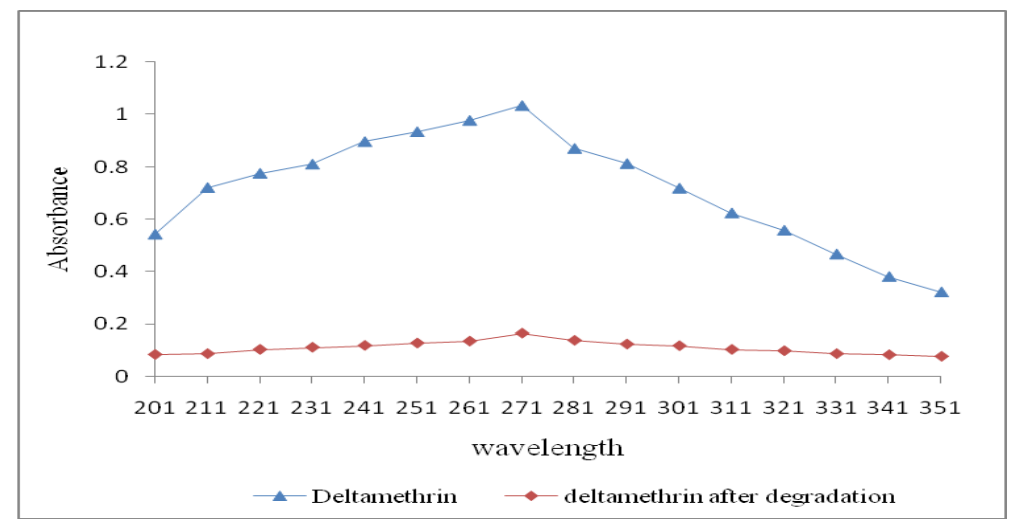

Fig.2A FTIR Spectrum of Control Deltamethrin, 2B. FTIR Spectrum of Metabolites Obtained after Degradation Deltamethrin
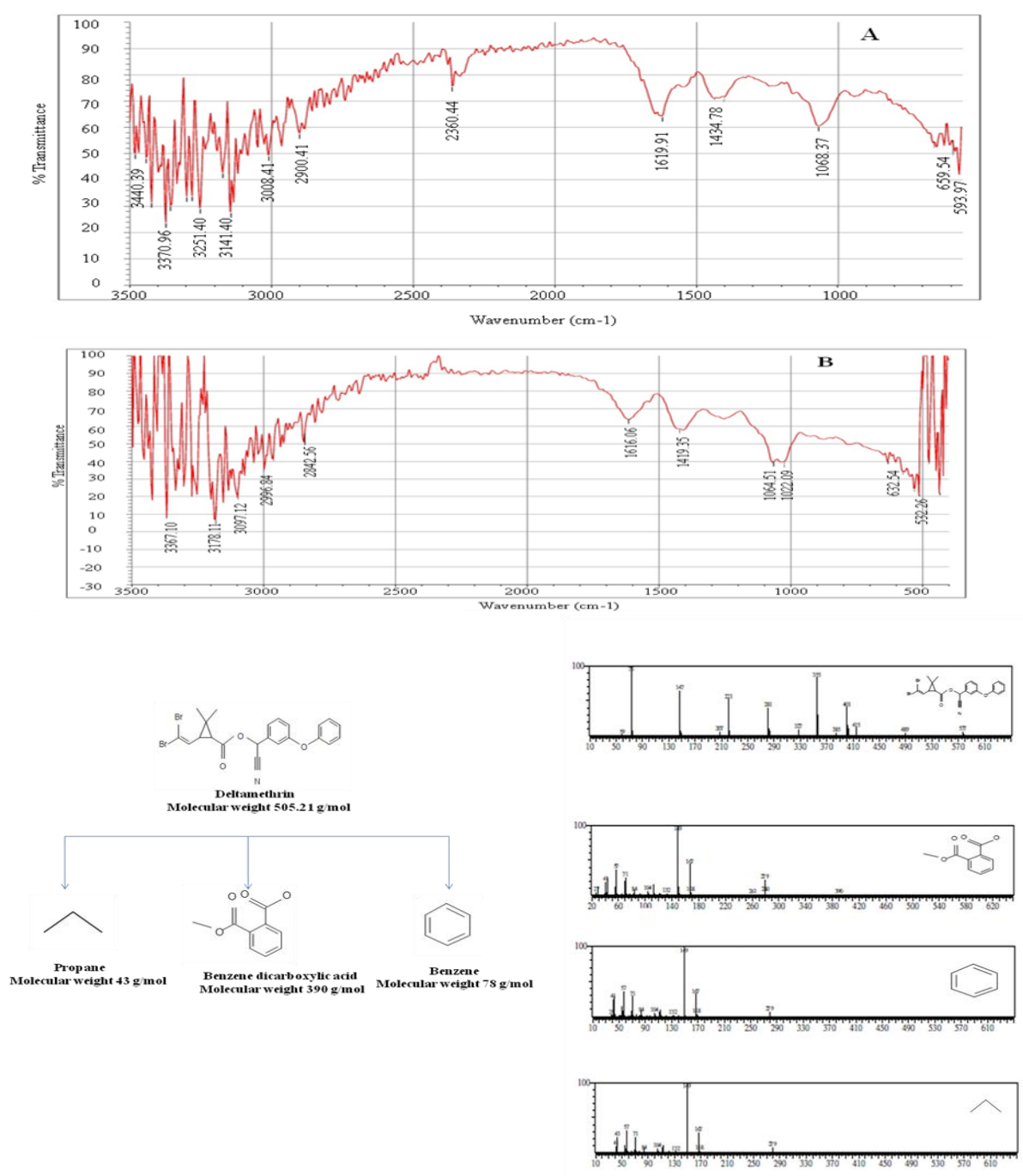

Figure 3. Proposed degradation pathway of Deltamethrin by isolate IK2a 
The investigation of microbial degradation of deltamethrin may be useful for the development of insecticide degradation strategies using microorganisms and/or enzymes involved in their hydrolysis. Maloney et al. (1993) reported Bacillus cereus, Pseudomons fluorescens species and bacteria from the Achromobacter genus are capable of decomposing delthametrin with the concentration of $50 \mu \mathrm{g} \mathrm{dm} 3$ in the presence of Tween 80 . According to Tallur et al. (2008) Sing et al. (2002), deltamethrin is degradable by bacteria from the Microccocus sp. Liu et al. (2010) studied that in the natural environment, deltamethrin can be degraded through several possible processes, including volatilization, photolysis, hydrolysis, and biodegradation. In oxygen cultures, the half-life of these microorganisms ranges from 21 to 28 days. Khan et al. (1988), studied that biodegradation is the principal pathway for degradation of deltamethrin in the environment. Chapman et al. (1981), Zhang et al. (1984), Grant and Betts (2004) reported that degradation of deltamethrin is slower under anaerobic or sterile conditions, indicating important role of soil microorganisms in this process. The present work also relates with the above mentioned work.

\section{Acknowledgement}

The authors are very grateful to the Director, Rayat Institute of Research and Development, Satara (MS), India and Principal, Bharati Vidyapeeth's MBSK Kanya Mahavidyalaya, Kadegaon, Dist. Sangli (M.S.) for extending the laboratory facilities to complete the investigation.

\section{References}

Abdallah, F.B., Hamden, K., GaleraudDenis, I., Feki, A.E., Keskes-
Ammar, L. 2009. An in vitro study on reproductive toxicology of deltamethrin on rat spermatozoa. Andrologia, 42: 254-259.

Aksakal, E., Ceyhun, S.B., Erdoğan, O., Ekinci, D. 2010. Acute and longterm genotoxicity of deltamethrin to insulin-like growth factors and growth hormone in rainbow trout. Comp. Biochem. Phys., 152: 451455.

Ardley, J.H. 1999. Pesticide considerations on environmental concern. Agri. Sci., 12(2): 21-24.

Bhanu, S., Archana, S., Ajay, K., Bhatt, J.L., Bajpai, S.P., Singh, P.S., Vandana, B. 2011. Impact of deltamethrin on environment, use as an insecticide and its bacterial degradation: A preliminary study. Int. J. Environ Sci., 1(5): 977-985.

Chapman, R.A., Tu, C.M., Harris, C.R., Cole, C. 1981. Persistence of five pyrethroid insecticides in sterile and natural, mineral and organic soil. Bull. Environ. Contam. Toxicol., 26: 513-519.

Dubey, K.K., Fulekar, M.H. 2011. Effect of pesticides on the seed germination of Cenchrus setigerus and Pennisetum pedicellatum as monocropping and co-cropping system: implications for rhizospheric bioremediation. Rom. Biotech. Lett., 16: 5908-5918.

Elliott, M. 1995. Chemicals in insect control. In: Casida JE, Quistad GB (eds) Pyrethrum flowers: production, chemistry, toxicology, and uses. Oxford University Press, NY.

Grant, R.J., Betts, W.B. 2004. Mineral and carbon usage of two synthetic pyrethroid degrading bacterial isolates. J. Appl. Microbiol., 97: 656-662.

Katsuda, Y. 1999. Development of and future prospects for pyrethroid 
chemistry. Pestic. Sci., 55(8): 775782.

Khan, S.U., Bekhi, R.M., Tapping, R.I., Akhbar, M.H. 1988. Deltamethrin residues in an organic soil under laboratory conditions and its degradation by bacterial strain. $J$. Agric. Food Chem., 36: 636-638.

Laffin, B., Chavez, M., Pine, M. 2010. The pyrethroid metabolites 3phenoxybenzoic acid and 3phenoxybenzyl alcohol do not exhibit estrogenic activity in the MCF-7 human breast carcinoma cell line or Sprague-Dawley rats. Toxicol., 267: 39-44.

Lawskowski, D.A. 2002. Physical and chemical properties of pyrethroid. Reviews of Environmental Contamination and Toxicology, 174: 49.

Liu, P.Y., Liu, Y.J., Liu, Q.X., Liu, J.W. 2010. Photodegradation mechanism of deltamethrin and fenvalerate. $J$. Environ. Sci., 22(7): 1123-1128.

Maloeny, S.E., Maule, A., Smith, A.R.W. 1993. Purification and preliminary characterization of permethrinase from a pyrethroid-transforming strain of Bacillus cereus. Appl. Environ. Microbiol., 59: 2007-2013.

McKinlay, R., Plant, J.A., Bell, J.N., Voulvoulis, N. 2008. Endocrine disrupting pesticides: implications for risk assessment. Environ. Int., 34: 168-183.

Parte, S., Rokade, K., Mali, G., Kudale, S. 2013. Biodegradation of sulfonated aromatic amine by Pseudomonas Desmolyticum NCIM 2112. Journal of Chemical and Pharmaceutical Research, 5(4): 335-339.

Perry, M.J., Venners, S.A., Barr, D.B., Xu, X.P. 2007. Environmental pyrethroid and organophosphorus insecticide exposures and sperm concentration.
Reprod. Toxicol., 23: 113 -118.

Rokade, K., Mali, G. 2013. Biodegradation of chlorpyrifose by Pseudomonas Desmolyticum 2112. Int. J. Pharma and Bio sci., 4(2): (B) 609-616.

Shafer, T.J., Meyer, D.A., Crofton, K.M. 2005. Developmental neurotoxicity of pyrethroid insecticides: critical review and future research needs. Environ. Health Perspect., 113(2): 123-136.

Shukla, Y., Yadav, A., Arora, A. 2002. Carcinogenic and cocarcinogenic potential of cypermethrin on mouse skin. Cancer Lett., 182: 33-41.

Sing, B.K., Walker, A., Wright, D.J. 2002. Persistence of chloropyriphos, fenamiphos, chlorothelonil and pendimethalin in soil and their effects on soil microbial characteristics. Bulletin of Environmental Contamination and Toxicology, 69: 181-188.

Tallur, P.N., Megadi, V.B., Ninnekar, H.Z. 2008. Biodegradation of cypermethrin by Micrococcus sp. strain CPN 1. Biodegradation, 19: 77-82.

Wang, C., Chen, F., Zhang, Q., Fang, Z. 2009b. Chronic toxicity and cytotoxicity of synthetic pyrethroid insecticide cis-bifenthrin. J. Environ. Sci., 21: 1710-1715.

Wolansky, M.J., Harrill, J.A. 2008. Neurobehavioral toxicology of pyrethroid insecticides in adult animals: a critical review. Neurotoxicol. Teratol., 30: 55-78.

Zhang, C., Jia, L., Wang, S.H., Qu, J., Xu, L.L., Shi, H.H., Yan, Y.C. 2010. Biodegradation of beta-cypermethrin by two Serratia spp. with different cell surface hydrophobicity. Bioresour. Technol., 101: 34233429.

Zhang, L.Z., Khan, S.U., Akhtar, M.H., 
Ivarson, K.C. 1984. Persistence, degradation, and distribution of deltamethrin in an organic soil under laboratory conditions. J. Agric. Food Chem., 32: 1207-1211.
Wang, L.M., Gan, J.Y. 2008 Estrogenic activity of lambdacyhalothrin in the MCF-7 human breast carcinoma cell line. Environ. Toxicol. Chem., 27(5): 1194-1200.

Zhao, M.R., Zhang, Y., Liu, W.P., Xu, C.,

\section{How to cite this article:}

Pawar, A.S., G.V. Mali and Deshmukh, H.V. 2016. Biodegradation of Deltamethrin by using Indigenous Bacteria Isolated from Contaminated Soil. Int.J.Curr.Microbiol.App.Sci. 5(5): 258265. doi: http://dx.doi.org/10.20546/ijcmas.2016.505.028 